\title{
Interannual Variability of Summer Surface Air Temperature over Central India: Implications for Monsoon Onset
}

\author{
ZHEN-QIANG ZHOU AND RENHE ZHANG \\ Department of Atmospheric and Oceanic Sciences and Institute of Atmospheric Sciences, Fudan University, Shanghai, China \\ SHANG-PING XIE \\ Scripps Institution of Oceanography, University of California, San Diego, La Jolla, California, and Physical \\ Oceanography Laboratory/CIMST, Ocean University of China, and Qingdao National Laboratory for \\ Marine Science and Technology, Qingdao, China
}

(Manuscript received 9 October 2018, in final form 26 December 2018)

\begin{abstract}
Year-to-year variability of surface air temperature (SAT) over central India is most pronounced in June. Climatologically over central India, SAT peaks in May, and the transition from the hot premonsoon to the cooler monsoon period takes place around 9 June, associated with the northeastward propagation of intraseasonal convective anomalies from the western equatorial Indian Ocean. Positive (negative) SAT anomalies during June correspond to a delayed (early) Indian summer monsoon onset and tend to occur during post-El Niño summers. On the interannual time scale, positive SAT anomalies of June over central India are associated with positive SST anomalies over both the equatorial eastern-central Pacific and Indian Oceans, representing El Niño effects in developing and decay years, respectively. Although El Niño peaks in winter, the correlations between winter El Niño and Indian SAT peak in the subsequent June, representing a post-El Niño summer capacitor effect associated with positive SST anomalies over the north Indian Ocean. These results have important implications for the prediction of Indian summer climate including both SAT and summer monsoon onset over central India.
\end{abstract}

\section{Introduction}

Daily mean surface air temperature (SAT) over central India shows prominent seasonal variations with a maximum (above $33^{\circ} \mathrm{C}$ ) in May (not July as is typical for the Northern Hemisphere) and a minimum (below $18^{\circ} \mathrm{C}$ ) in January (Fig. 1a). Central India SAT decreases sharply in June from $33.6^{\circ} \mathrm{C}$ (1 June) to $28.5^{\circ} \mathrm{C}$ (30 June) with the onset of the summer monsoon (or the so-called southwest monsoon, named after the direction of prevailing surface wind). Hereafter, seasons refer to those for the Northern Hemisphere.

The Indian summer monsoon (ISM) brings over 70\% of the annual rainfall in India (Parthasarathy et al. 1994), with an abrupt onset (with rainfall increasing from 3.7 to $12.5 \mathrm{~mm} \mathrm{day}^{-1}$ ) in June and gradual withdrawal (from 9.8 to $3.8 \mathrm{~mm} \mathrm{day}^{-1}$ ) in September (Fig. 1a). The ISM impacts the livelihood of more than one-fifth of the world's population, including agriculture production,

\footnotetext{
Corresponding author: Renhe Zhang, rhzhang@fudan.edu.cn
}

water availability, and food security (Wahl and Morrill 2010). ISM rainfall displays large interannual variability, which sometimes leads to droughts and floods over different parts of the country (Gadgil 2003; Mishra et al. 2012). Substantial losses occur in agricultural output (Parthasarathy et al. 1992) and reduction in gross domestic product (GDP; Gadgil and Gadgil 2006) during drought years. Thus, it is important to predict ISM rainfall.

Figure 2 shows the year-to-year standard deviation of India SAT for each calendar month for the period of 1901-2016. Large variability over northwestern India and Pakistan during March-May (Chowdary et al. 2014) is related to heat-wave events causing high mortality in India. For example, over 1300 people died in Ahmedabad because of heat waves in 2010, prompting the coordinated Heat Action Plans (Knowlton et al. 2014). However, the effect is limited and heat waves in 2015 killed more than 2500 people (Mazdiyasni et al. 2017). Maximum temperatures in Jaisalmer reached $52.4^{\circ} \mathrm{C}$ in May of 2016, making it the most intense heat wave in recorded history (Mazdiyasni et al. 2017). 
a) Climatology

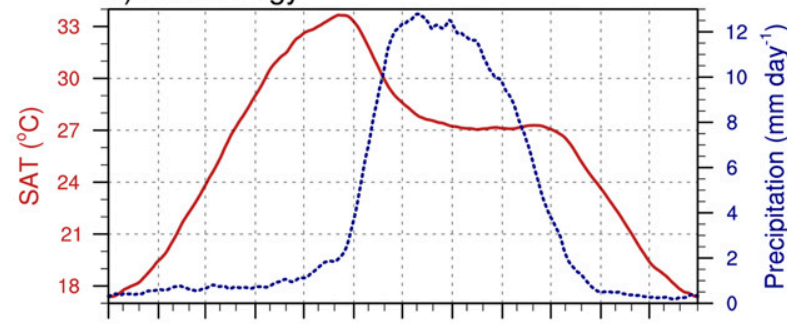

b) STD

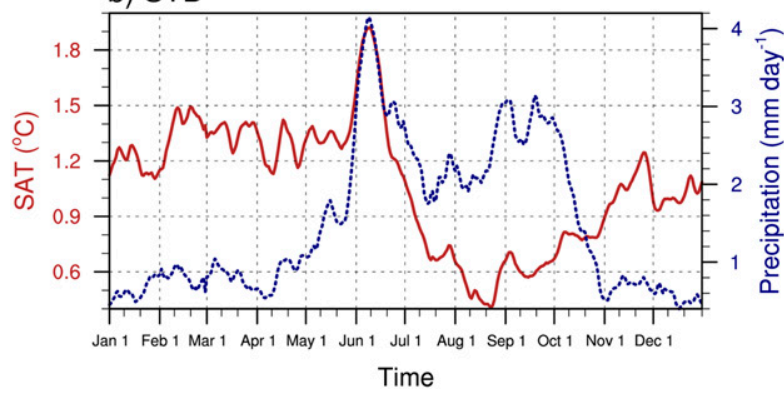

FIG. 1. (a) Climatology and (b) year-to-year standard deviation of daily mean SAT $\left({ }^{\circ} \mathrm{C}\right.$; solid red curves) and precipitation $\left(\mathrm{mm} \mathrm{day}^{-1}\right.$; dashed blue curves) over central India $\left(18^{\circ}-28^{\circ} \mathrm{N}, 76^{\circ}-\right.$ $86^{\circ} \mathrm{E}$; blue box in Fig. 2) during 1958-2013. An 11-day low-pass filter is applied to remove synoptic variations.

Central India (marked by the blue box in Fig. $2 ; 18^{\circ}-$ $28^{\circ} \mathrm{N}, 76^{\circ}-86^{\circ} \mathrm{E}$ ) experiences pronounced interannual variability of SAT, especially in June with a standard deviation over $1.25^{\circ} \mathrm{C}$ (Fig. 2). June is the onset month of the ISM, after which air temperature cools down as monsoonal rainfall wets the land surface.

The date of ISM onset is declared by the Indian Meteorological Department (IMD) each year as the date of the monsoon onset at Kerala (MOK; Kerala is located in the southwest corner of India), based on subjective estimates prepared by operational forecasters until 2005 (Rao 1976; Joseph et al. 1994). The long-term mean date of MOK is around 1 June with a standard deviation of 8-9 days (Ananthakrishnan and Soman 1988). The earliest date of MOK and the most delayed one during the last 100 years differ by 46 days (7 May and 22 June, respectively). The average date of the monsoon onset over central India is about 10 days after the MOK onset. There are also some other objective definitions of the onset date ranging from being based simply on rainfall (Ananthakrishnan et al. 1967; Sperber and Annamalai 2014; Noska and Misra 2016) to a more comprehensive outlook of wind field, rainfall, and outgoing longwave radiation (Joseph et al. 2006; Taniguchi and Koike 2006; Pai and Rajeevan 2007; Wang et al. 2009), moisture transport (Fasullo and Webster 2003), upper-level meridional temperature gradient (Li and Yanai 1996; Goswami et al. 2006;
Xavier et al. 2007), and precipitable water (Zeng and Lu 2004; Lu et al. 2009). These objective methods show consistent interannual variability with the subjective ISM onset date although these definitions are inadequate and often untimely for rural agrarian applications over central India (Misra et al. 2018).

Various hypotheses have been proposed to explain the ISM onset variability. Murakami et al. (1986) suggested that the intraseasonal oscillation (ISO), with periods of 24-91 days, is important in determining the onset date of the summer monsoon over south Asia. Joseph et al. (1994) found that 16 of the 22 delayed MOK cases between 1870 and 1989 are associated with a moderate or strong El Niño event, particularly in year 1 (where years 0 and 1 denote the developing and decay years of an El Niño event, respectively). El Niño-related positive SST anomalies in the equatorial central Pacific delay the seasonal northwestward movement of the equatorial convective cloudiness maximum, and negative (positive) SST anomalies in the Arabian Sea (the south Indian Ocean) may play a similar role.

The present study investigates interannual variations in summer SAT over central India. There, the transition from the hot premonsoon to the cooler monsoon period takes place around 9 June and is related to the local ISM onset. We show that positive SAT anomalies in June are associated with a delayed ISM onset and tend to occur during post-El Niño summers. The monsoon onset tends to be associated with the northeastward propagation of an intraseasonal convective anomaly from the western equatorial Indian Ocean. On the interannual time scale, El Niño-related positive SST anomalies over the equatorial eastern-central Pacific and Indian Oceans delay the ISM onset in developing and decay years, respectively.

In the following, section 2 describes the datasets and methods. Section 3 presents the relationship between SAT in June and summer monsoon onset over central India. Section 4 investigates characteristics of the ISO related to ISM onset. Section 5 discusses the effect of ENSO on India SAT. Section 6 is a summary and discussion.

\section{Datasets and methods}

We use the monthly mean precipitation and temperature datasets from the Climate Research Unit, version TS 4.01 (CRU TS4.01, Harris et al. 2014). These datasets have been interpolated from meteorological stations, based on spatial autocorrelation functions, and included data for a 116-yr period from 1901 to 2016 at $0.5^{\circ} \times 0.5^{\circ}$ spatial resolution. We also use 6-hourly and monthly mean temperature, precipitation, zonal and meridional wind fields, and velocity potential from the Japanese 55-year Reanalysis (JRA-55; Kobayashi et al. 2015) released by the Japan Meteorological Agency (JMA) for a 56-yr 
SAT STD: $1901-2016$

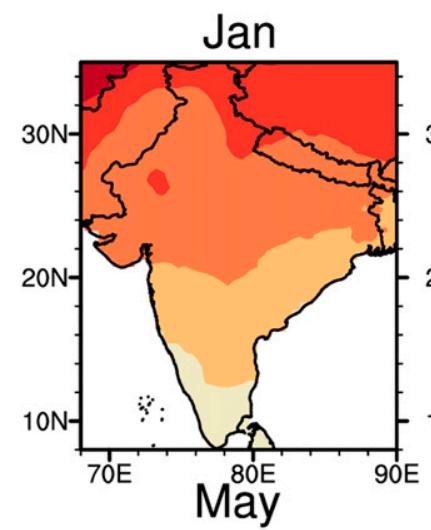

Feb
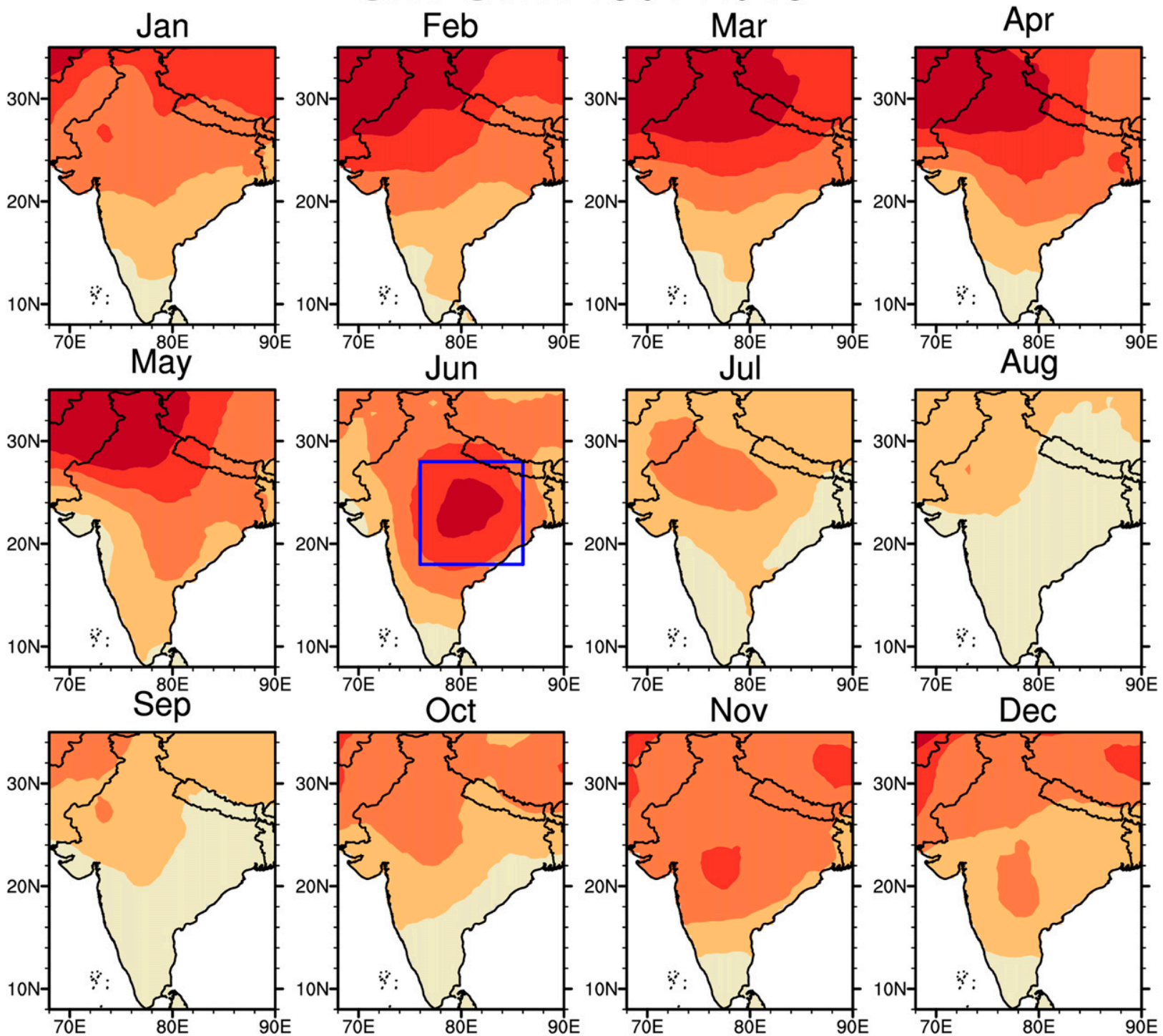

1.25

FIG. 2. Year-to-year standard deviation of SAT $\left({ }^{\circ} \mathrm{C}\right.$; color shading) over India for each calendar month during $1901-2016$.

period from 1958 to 2013 with a $1.25^{\circ} \times 1.25^{\circ}$ spatial resolution and 27 vertical pressure levels from 1000 to $100 \mathrm{hPa}$. The 6-hourly data are interpolated from hybrid model levels to the standard pressure levels. We calculate daily mean values from 6-hourly datasets for all variables. Daily interpolated outgoing longwave radiation (OLR) from NOAA is available on a $2.5^{\circ} \times 2.5^{\circ}$ spatial grid for a 34-yr period from 1979 to 2012 (Lee 2014). OLR is used as a proxy for large-scale convective activity in the tropics. We also use the monthly mean Extended Reconstructed Sea Surface Temperature version 5 (ERSST.v5) dataset on a $2^{\circ}$ latitude $\times 2^{\circ}$ longitude grid for a 116 -yr period from 1901 to 2016 (Huang et al. 2017).

\section{Relationship between SAT in June and ISM onset over central India}

\section{a. Climatology and year-to-year variability}

Figure $3 \mathrm{a}$ shows the probability distribution function (PDF) of daily mean SAT over central India $\left(18^{\circ}-28^{\circ} \mathrm{N}\right.$, $76^{\circ}-86^{\circ} \mathrm{E}$; blue box in Fig. 2) in May (red curve), June (black curve), and July (blue curve) based on the JRA-55 

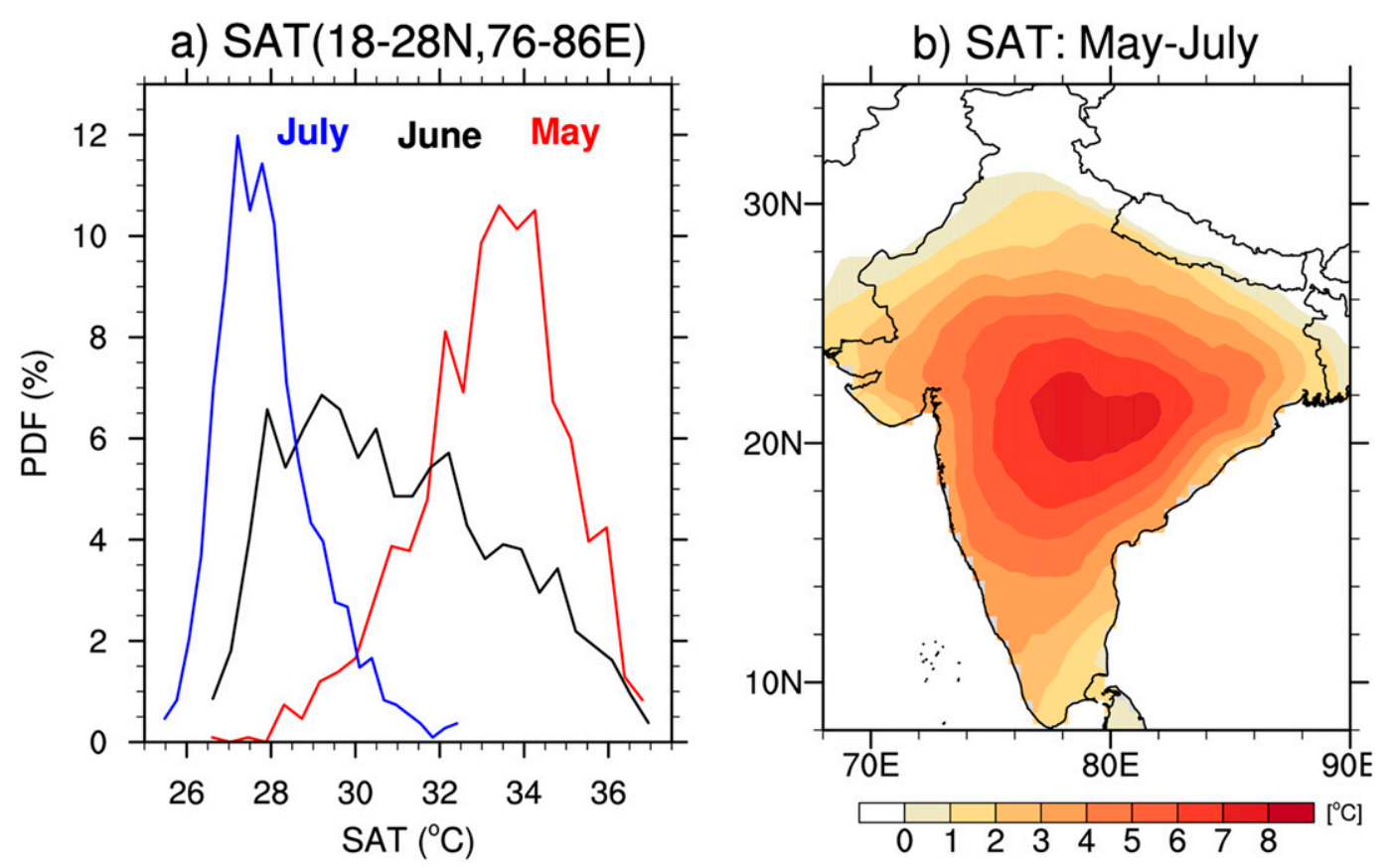

FIG. 3. (a) Estimates of probability distribution functions (PDFs) of daily mean SAT $\left({ }^{\circ} \mathrm{C}\right)$ over central India $\left(18^{\circ}-28^{\circ} \mathrm{N}\right.$, $76^{\circ}-86^{\circ} \mathrm{E}$; blue box in Fig. 2) in May (red curve), June (black curve), and July (blue curve) for 1958-2013. (b) Difference of SAT $\left({ }^{\circ} \mathrm{C}\right.$; color shading) climatology between May and July.

dataset for 1958-2013. Daily mean SAT decreases markedly from May to July. Daily mean SAT over central India peaks around $34^{\circ} \mathrm{C}$ in May, which is the hottest (premonsoon) month in India. With the onset of the India summer monsoon, daily mean SAT drops to around $27^{\circ} \mathrm{C}$ in July. Notably, daily mean SAT shows a much broader distribution $\left(26.5^{\circ}-37^{\circ} \mathrm{C}\right)$ in June than in both May and July. The spatial distribution of May-July SAT differences shows a large peak of more than $7^{\circ} \mathrm{C}$ (Fig. 3b). Thus June is a transitional period from a dry hot premonsoon to a wet moderate monsoon regime. Interannual variability in the monsoon onset can result in large variability in June SAT.

There are two significant peaks in year-to-year standard deviation of daily mean rainfall over central India (Fig. 1b), one in June and the other one in September, due to the strong interannual variability in ISM onset (Ananthakrishnan and Soman 1988) and withdrawal, respectively. The year-to-year variability of rainfall is larger in June than in September. In contrast, daily mean rainfall shows relative small year-to-year variability during both July and August with its climatology reaching above $10 \mathrm{~mm}$ day $^{-1}$ during these two months.

Year-to-year variability of daily mean SAT over central India increases sharply in June (Fig. 1b), coinciding with a similar increase in rainfall variance. The standard deviation of daily mean SAT peaks at $1.9^{\circ} \mathrm{C}$ around 9 June, the climatological onset date of local summer monsoon over central India, which suggests a relationship to interannual variability of ISM onset. Daily mean SAT is high (low) on 9 June in late (early) ISM onset years. The year-to-year standard deviation of SAT drops during both mature phase (July and August) and withdrawal (September) of the summer monsoon, damped by surface evaporation on wet land surface (Zhang et al. 2011; Ito et al. 2013).

Therefore, the prominent interannual variability of monthly mean SAT over central India in June (Fig. 2) is probably related to variability of daily mean SAT (Fig. 1b), which is caused by strong interannual variations of ISM onset. Specifically, positive SAT anomalies in June correspond to a late ISM onset, and vice versa.

\section{b. Year-to-year variability of the ISM onset process}

Across the ISM onset over central India, daily mean SAT decreases sharply with the abrupt increase of monsoonal rainfall (Fig. 1a). However, this process of SAT decrease might be different from one year to another due to the large interannual variability in ISM onset. We perform an empirical orthogonal function (EOF) analysis on interannual variability in daily mean SAT over central India from 28 May to 19 June during 1958-2013 (Fig. 4). Eigenvectors are 23-day-long time series of daily mean SAT anomalies and principal components (PCs) are time series that are 66 years long.

The first EOF mode captures $74.2 \%$ of SAT total variance (Fig. 4). Daily mean SAT anomalies are of the 
a) EOF1: $74.2 \%$
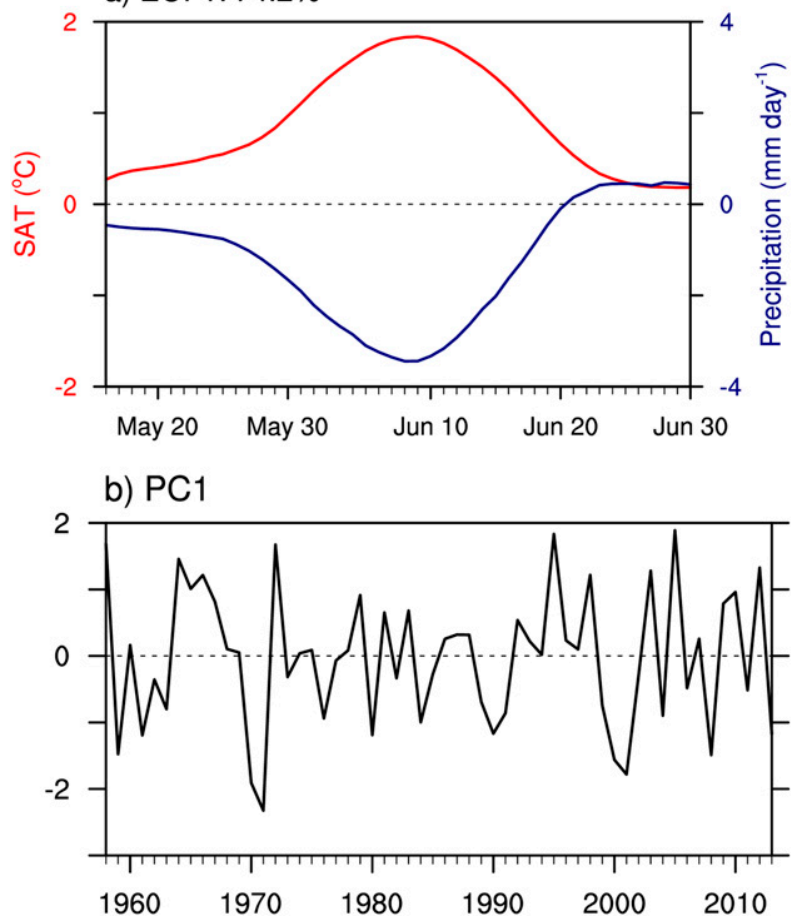

FIG. 4. Anomalies of (a) daily mean SAT (red curve) and precipitation (blue curve) regressed against (b) PC1 (explains $74.2 \%$ of total variance) of daily mean SAT year-to-year variability over central India $\left(18^{\circ}-28^{\circ} \mathrm{N}, 76^{\circ}-86^{\circ} \mathrm{E}\right.$; blue box in Fig. 2$)$ from 28 May to 19 June during $1958-2013$.

same sign during the whole month of June with a peak on 9 June (Fig. 4a). This explains why PC1 is highly correlated with monthly mean SAT anomalies over central India in June at 0.92 (Fig. 6). Again, this indicates that the prominent year-to-year variability of June monthly mean SAT over central India (Fig. 2) is due to EOF1.

Figure 5 shows the composites of daily mean SAT and precipitation over central India in years with positive PC1.

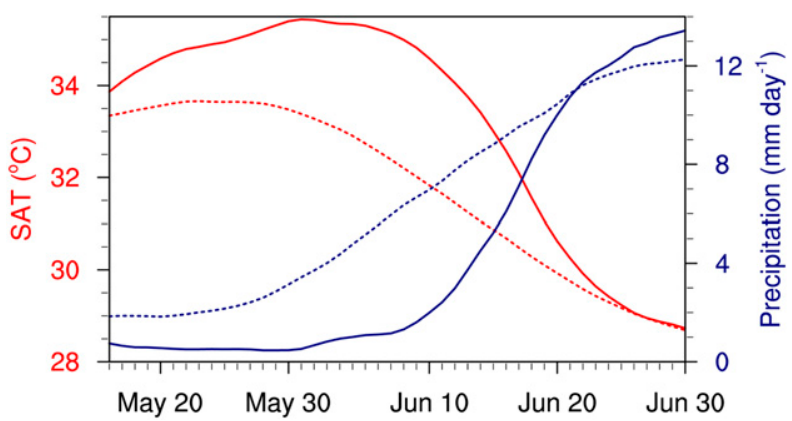

FIG. 5. Composites of daily mean SAT (solid red curve) and precipitation (solid blue curve) in years with positive PC1 (Fig. 4b). Climatological daily mean SAT (dashed red curve) and precipitation (dashed blue curve) are also plotted for comparison.

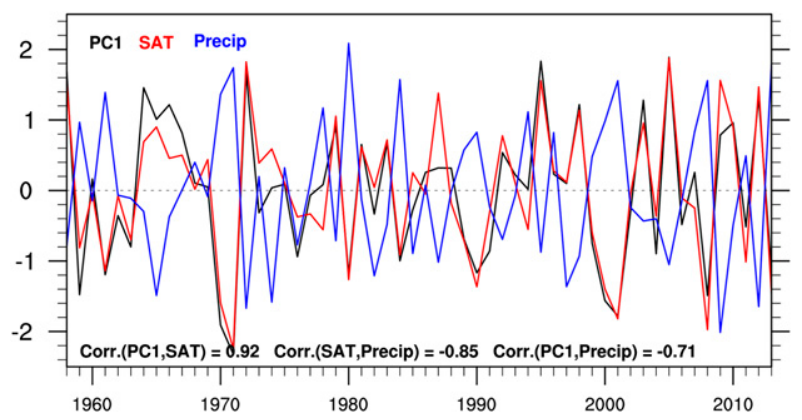

FIG. 6. PC1 (black curve) in Fig. $4 \mathrm{~b}$ and monthly mean SAT $\left({ }^{\circ} \mathrm{C}\right.$; red curve) and precipitation (mm day ${ }^{-1}$; blue curve) anomalies of June over central India $\left(18^{\circ}-28^{\circ} \mathrm{N}, 76^{\circ}-86^{\circ} \mathrm{E}\right.$; blue box in Fig. 2$)$ during 1958-2013.

Climatological daily mean SAT and precipitation (dashed curves in Figs. 1a and 5) are also plotted for comparison. In years with positive PC1, monsoonal rainfall increases sharply (from 1.5 to $11 \mathrm{~mm} \mathrm{day}^{-1}$ ) from 9 to 20 June (solid blue curve in Fig. 5). This monsoon onset is about 10 days later than the climatology (dashed blue curve in Fig. 5). As a result, daily mean SAT is much hotter than the climatology throughout the month of June (red curves in Figs. 4 and 5). Actually, PC1 agrees well with year-to-year variability of ISM onset date based on subjective IMD definition. The linear correlation coefficient is 0.55 (over $99 \%$ significant level) for the 48-yr period of 1958-2005. The positive (negative) phase of EOF1 corresponds a late (early) ISM onset over central India.

In addition, $\mathrm{PC} 1$ is negatively correlated with monthly mean rainfall anomalies of June at -0.72 (Fig. 6). The traditional idea that monsoons are driven by land-sea thermal contrast would predict that hotter-than-normal premonsoon SAT over India is followed by a strong monsoon (e.g., Bryson and Campbell 1982) but June SAT shows a negative relationship with seasonal [JuneSeptember (JJAS)] mean rainfall anomalies over central India (the whole country) at $-0.51(-0.41)$ on the interannual time scale based on the CRU dataset for 19012016 (Table 1). This indicates that a weak monsoon occurs during years with positive June SAT anomalies over India. This negative relationship is largely due to decreased rainfall in June during years of late ISM onset over central India (as will be discussed further), as the correlation coefficient between June SAT and June (JAS) rainfall

TABLE 1. Correlation coefficients between the June SAT index (over central India) and the June, the June-September (JJAS) mean, and the July-September (JAS) mean precipitation (precip) over central India and for all of India (in parentheses) during 1901-2016.

\begin{tabular}{lccc}
\hline \hline & June precip & JJAS precip & JAS precip \\
\hline SAT & $-0.85(-0.81)$ & $-0.51(-0.41)$ & $0.03(0.03)$ \\
\hline
\end{tabular}



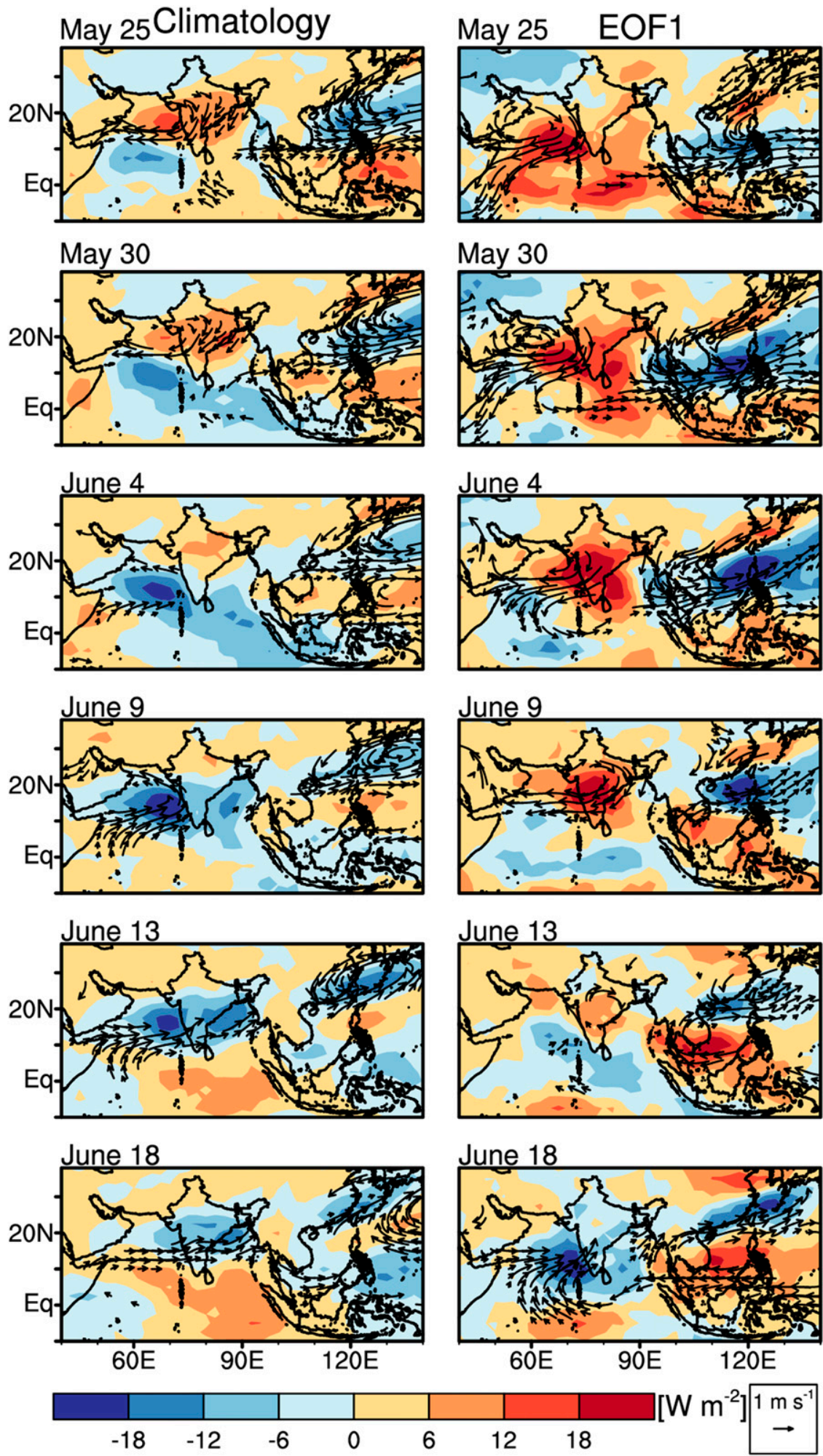

FIG. 7. Composite 20-100-day bandpass-filtered daily anomalies of OLR ( $\mathrm{W} \mathrm{m}^{-2}$; shading) and $850-\mathrm{hPa}$ winds ( $\mathrm{m} \mathrm{s}^{-1}$; vectors) from 25 May to 18 June for (left) climatology and (right) positive minus negative phase of EOF1. Both winds and OLR anomalies in EOF1 are shortened to a half for comparison. Only wind anomalies above $0.5 \mathrm{~m} \mathrm{~s}^{-1}$ are plotted. 


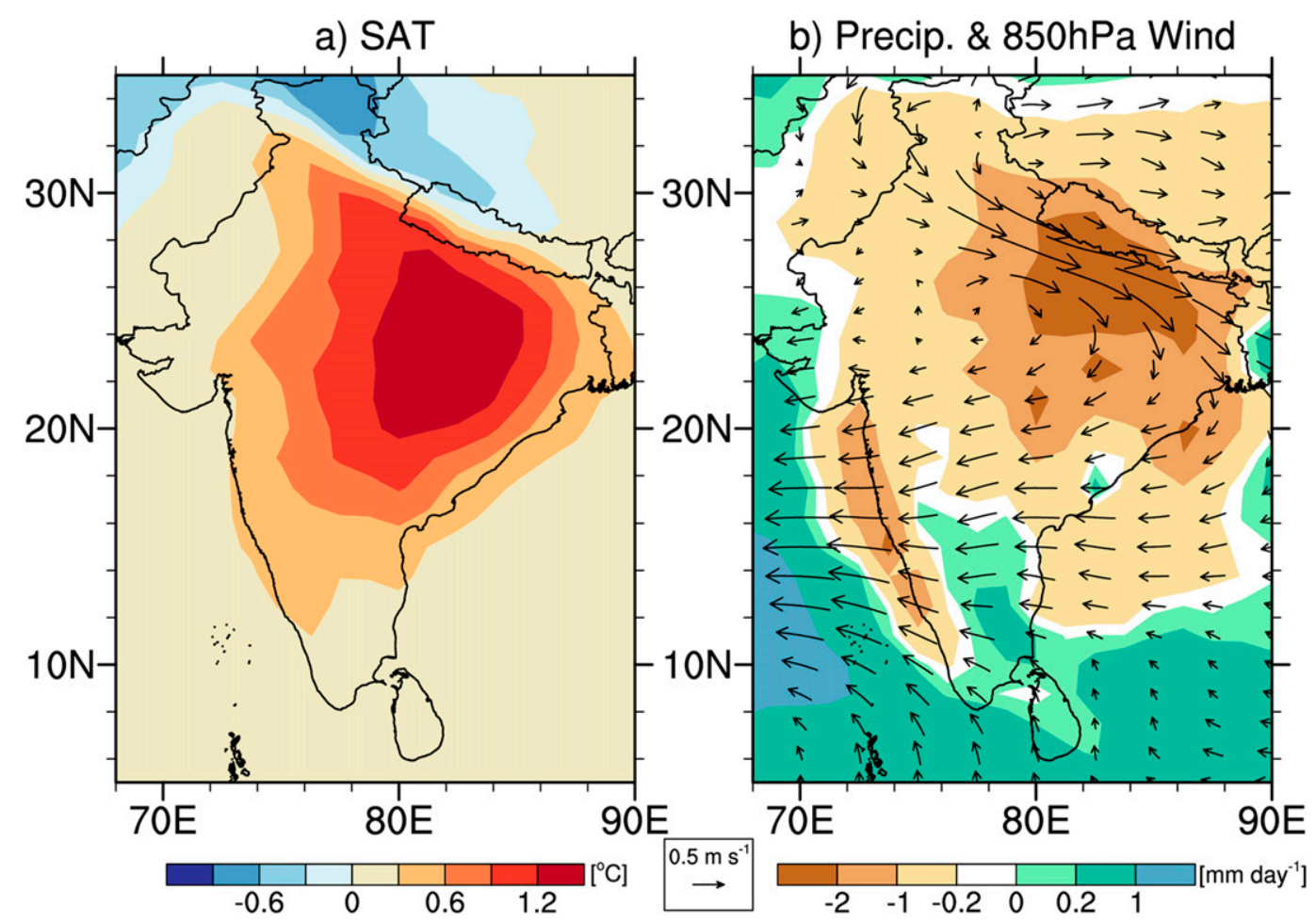

FIG. 8. Anomalies of June (a) SAT $\left({ }^{\circ} \mathrm{C}\right.$; color shading) and (b) precipitation (mm day ${ }^{-1}$; color shading) and 850-hPa winds ( $\mathrm{m} \mathrm{s}^{-1}$; vectors) regressed against PC1 (Fig. 4b) of daily mean SAT year-to-year variability over central India $\left(18^{\circ}-28^{\circ} \mathrm{N}, 76^{\circ}-86^{\circ} \mathrm{E}\right.$; blue box in Fig. 2) from 28 May to 19 June during $1958-2013$.

anomalies is $-0.85(0.03)$. Similarly, the correlation between June and JJAS (JAS) mean rainfall anomalies is at 0.63 (0.07). Thus, the correlation between premonsoon land-sea thermal contrast and monsoonal rainfall is limited to June and indicative of the latter causing the former on the interannual time scale (Biasutti et al. 2018), instead of the other way around.

\section{ISO related to ISM onset}

EOF1 includes significant intraseasonal variability (Murakami et al. 1986; Qi et al. 2008). To understand the effect of ISO onto ISM onset, the evolution of daily mean OLR and 850-hPa wind field anomalies related to the leading PC of daily mean SAT over central India (Fig. 4b) is composited from 25 May to 18 June.

Figure 7 shows the composite evolution pattern of 20-100-day-filtered OLR and 850-hPa wind anomalies from 25 May to 18 June for climatology (left panels) and positive minus negative phase of EOF1 (right panels). The climatological ISM onset date over central India is around 9 June when an active ISO convection anomaly moves from the equatorial western Indian Ocean to central India, where northeasterly wind anomalies turn to southwesterly wind anomalies (left panels in Fig. 7). Before the ISM onset, suppressed convection controls central India and the northeast Arabian Sea on 25 May. This premonsoon dry spell continues to advance northeastward to cover most of the Indian peninsula, and may cause serious heat waves over the whole country (e.g., Joseph et al. 1994; Wang et al. 2009). In the meantime, active ISO convection anomalies are initiated in the equatorial western Indian Ocean on 25 May, and follow the pathway of the previous dry ISO to move northeastward. There is an anomalous anticyclonic over the tropical eastern Indian Ocean, which transports water vapor from the Indian monsoon to East Asia (Zhang 2001). Around 30 May, this enhanced ISO convection reaches the west coast of southern India with a cyclonic anomaly, and the official ISM rainy season begins. The enhanced ISO convection continues to move northward with the strengthened southwest wind and reaches central India on 9 June, starting the local rainy season. The wind anomalies turn to southwesterly over central India after the ISM onset. The enhanced ISO convection continues to move northward and reaches $30^{\circ} \mathrm{N}$ on 18 June. The 850-hPa wind anomalies move together with the OLR anomalies as a Rossby wave response throughout the ISO evolution. Daily mean SAT over central India decreases sharply following the ISM onset from 30 May to 20 June (Figs. 1a and 5). 
a) TT \& 250hPa Wind

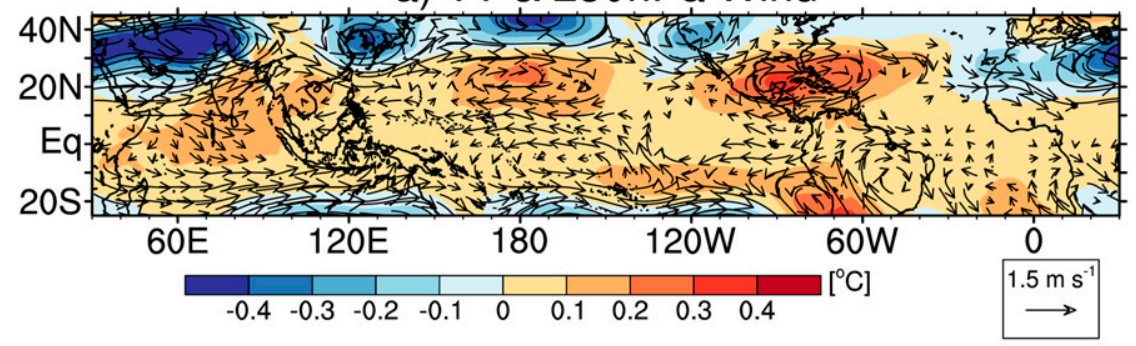

b) Rainfall \& $250 \mathrm{hPa}$ VP

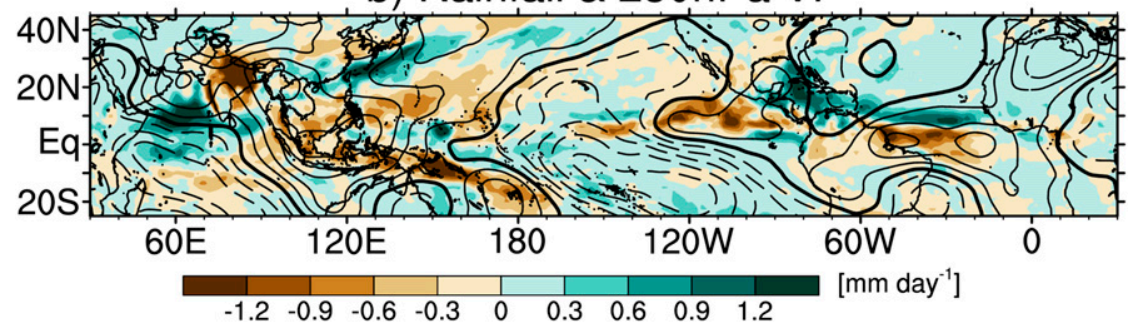

c) SST \& $850 \mathrm{hPa}$ Wind

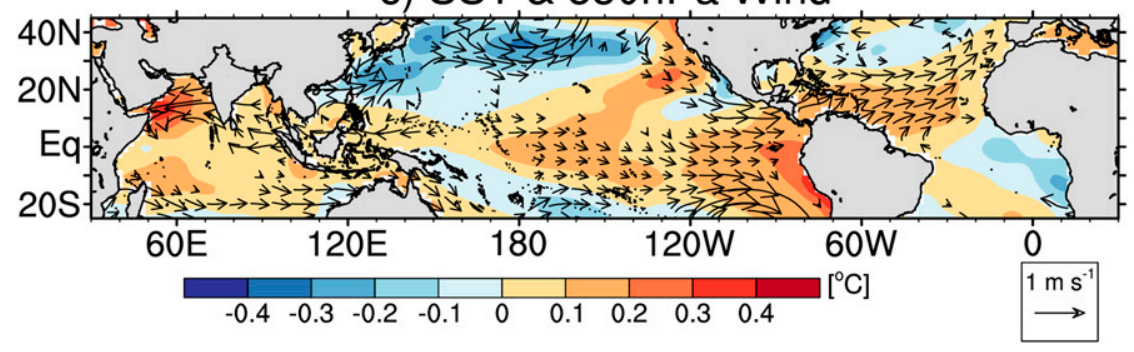

FIG. 9. As in Fig. 8, but for (a) tropospheric temperature $\left({ }^{\circ} \mathrm{C}\right.$; color shading) and $250-\mathrm{hPa}$ wind ( $\mathrm{m} \mathrm{s}^{-1}$; vectors), (b) rainfall (mm day ${ }^{-1}$; color shading) and $250-\mathrm{hPa}$ velocity potential (black contours; interval $=1 \times 10^{5} \mathrm{~m}^{2} \mathrm{~s}^{-1}$; thick contour for $0 \mathrm{~m}^{2} \mathrm{~s}^{-1}$; solid contours denote positive values and dashed contours denote negative values), and (c) SST ( ${ }^{\circ} \mathrm{C}$; color shading) and $850-\mathrm{hPa}$ wind $\left(\mathrm{m} \mathrm{s}^{-1}\right.$; vectors).

At the positive phase of EOF1 (right panels in Fig. 7), the premonsoon intraseasonal dry spell over India is much stronger than the climatology (left panels), and occupies the whole country with strong northeasterly wind anomalies until 13 June. The subsequent ISO convection reaches central India around 18 June, almost 10 days later than the climatology, signifying the beginning of the ISM rainy season over central India. With such a late ISM onset, daily mean SAT over central India is much higher than the climatology (Fig. 5).

Similar ISO evolution has been identified for ISM onset over Kerala by Joseph et al. $(1994,2006)$ and Wang et al. (2009). The present study relates ISO evolution to SAT variations over central India. Daily mean SAT decreases with the onset of monsoonal rainfall (climatologically on 9 June) over central India, which is largely modulated by northeastward-propagating ISO events on interannual time scale. Central India SAT is dominated by the first leading mode that represents large interannual variability in ISM onset ( $>10$ days) (Fig. 6). During early (late) ISM onset years, central India SAT anomalies are negative (positive) in June.

\section{ENSO effects on SAT over India}

Figure 8 shows anomalies of June SAT, rainfall, and 850-hPa winds regressed onto the leading PC (Fig. 4b) of daily mean SAT variability over central India from 28 May to 19 June during 1958-2013. Strong positive SAT anomalies occupy the whole country with a peak of $1.2^{\circ} \mathrm{C}$ over central India (Fig. 8a), due to the late onset of ISM as discussed above. The pattern resembles both the year-to-year standard deviation of SAT in June (Fig. 2) and the leading mode of interannual variability in seasonal mean SAT (averaged from June to September) (Chowdary et al. 2014). Rainfall anomalies exhibit a dipole structure with depressed rainfall over central and northern India and enhanced rainfall over peninsular 


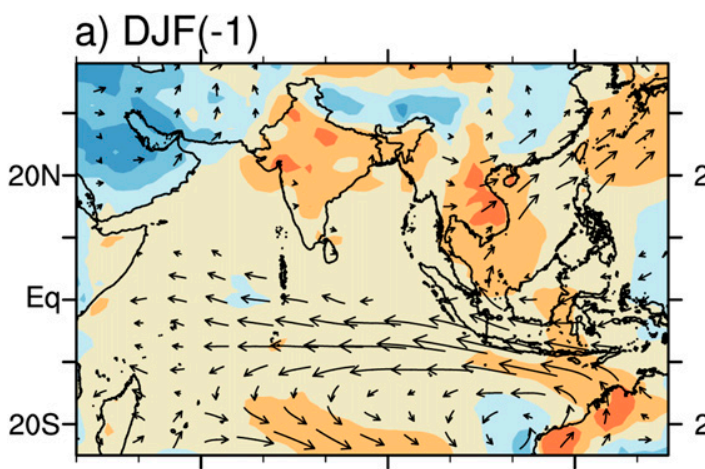

c) $\mathrm{JJA}(0)$

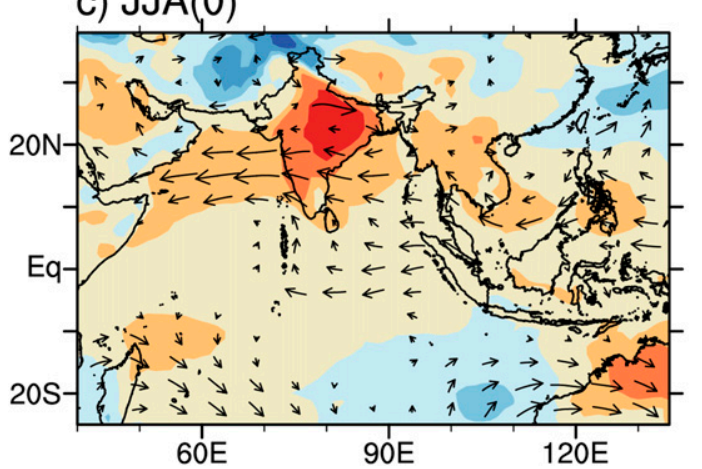

b) $\operatorname{MAM}(0)$

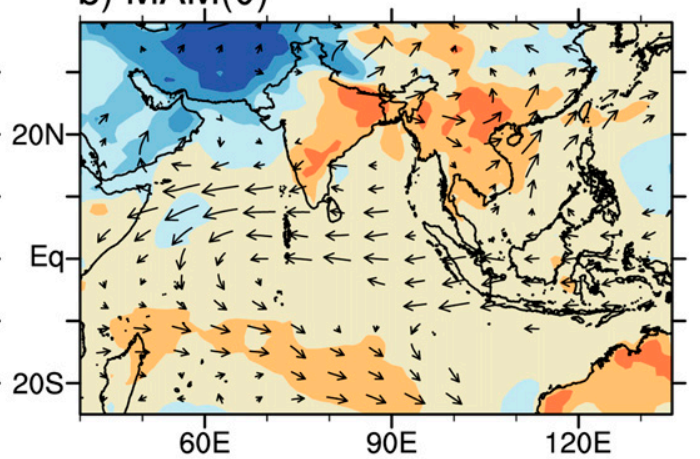

FIG. 10. As in Fig. 8, but for seasonal mean SAT $\left({ }^{\circ} \mathrm{C}\right.$; color shading) and 850 -hPa winds $\left(\mathrm{m} \mathrm{s}^{-1}\right.$; vectors) during

(a) the preceding winter (DJF) and the concurrent (b) spring [March-May (MAM)] and (c) summer (JJA).

India (Fig. 8b). The accompanying 850-hPa wind anomalies project onto the climatological mean summer monsoon circulation, representing a weakening of the westerly monsoon flow across peninsular India and northwesterly wind anomalies over northeastern India (Fig. 8b). This dipole pattern of rainfall anomalies in June largely resembles the second EOF mode of interannual variability in Indian summer monsoon rainfall (ISMR) averaged from June through September from 1900 to 2008 (Mishra et al. 2012). This mode of ISMR is coupled with SST variability over the Indian Ocean and is correlated with ENSO of preceding winter. Joseph et al. (1994) also found that 16 of the 22 (see their Table 3) delayed MOK cases between 1870 and 1989 occur during post-El Niño summers.

To examine the tropical SST effect onto June SAT over central India, Fig. 9 shows anomalies of SST, 850-hPa winds, rainfall, $250-\mathrm{hPa}$ velocity potential, tropospheric temperature, and $250-\mathrm{hPa}$ winds in June regressed onto the leading PC (Fig. 4b) of daily mean SAT anomalies over central India during 1958-2013. During late onset years, positive SST anomalies and westerly anomalies appear over the central-eastern Pacific, typical of a developing El Niño (Fig. 9c). Increased rainfall occurs over the warming central Pacific Ocean and decreased rainfall over India and the Maritime Continent (Fig. 9b; shading). These rainfall anomalies are linked by an anomalous Indo-Pacific Walker circulation, as seen in the 200-hPa velocity potential, which has a broad descending branch over South Asia (Fig. 9b; contours). This is consistent with previous studies showing that rainfall over India tends to be suppressed during the warm phase and enhanced during the cold phase of the ENSO cycle (Rasmusson and Carpenter 1983; Zhang et al. 1996; Kumar et al. 1999; Xie et al. 2009; Mishra et al. 2012; Xie and Zhou 2017; Zhou et al. 2018).

Over the Indo-northwestern Pacific (NWP) region, SST is anomalously high (Fig. 9c), with suppressed convection and an anomalous anticyclonic circulation over the tropical NWP extending to the northern Indian Ocean (Figs. 9b,c). The above anomalies of SST and circulation are associated with above-normal rainfall over peninsular India and below-normal rainfall in central and northern India (Fig. 9b). The tropical NWP anomalies further affect East Asia and South Asia (Wu and Yeh 2010; Srinivas et al. 2018) through a meridional Pacific-Japan (PJ) teleconnection pattern (Nitta 1987).

The above anomalies are known as the Indo-western Pacific Ocean capacitor (IPOC) effect, which often occurs 
during the decay phase of El Niño (Xie et al. 2009, 2016; Kosaka et al. 2013). Thus, positive SAT anomalies of June over central India are associated with positive SST anomalies over the equatorial eastern-central Pacific and Indian Oceans induced by El Niño in developing and decay years, respectively. Figure 10 shows the evolution of IPOC with seasonal mean anomalies of SAT and 850$\mathrm{hPa}$ winds, and a detailed description can be found in the above references. During the mature phase of El Niño [December-February (DJF)], an anomalous anticyclone forms in the southeast Indian Ocean (Fig. 10a), associated with a weakened Walker circulation. The anomalous anticyclone forces downwelling ocean Rossby waves that propagate westward, which cause the southwest Indian Ocean to warm by deepening the thermocline (Fig. 10b). The southwest Indian Ocean warming, anchored by the slow-propagating ocean Rossby waves, drives an asymmetrical pattern of anomalous atmospheric circulation over the tropical Indian Ocean in the spring and summer following the mature phase of El Niño, northeasterly north and northwesterly south of the equator (Figs. 10b,c). The anomalous northeasterly winds warm the north Indian Ocean after the onset of the southwest monsoon in May and June by reducing latent heat flux (Fig. 10c). This second warming of the north Indian Ocean excites a tropospheric Kelvin wave propagating to the western Pacific (Fig. 9a), forcing the anomalous anticyclone during summer [June-August (JJA); Fig. 10c].

The anomalous northeasterly winds cause positive SAT anomalies over India during post-El Niño summers (Fig. 10c). In fact, the JJA seasonal mean positive SAT anomalies over India are mainly due to anomalies in June. The above results remain the same if we use June SAT anomalies over central India instead of PC1 for the regressions. Warm SAT anomalies over India in June result from the delayed onset of monsoonal rainfall, and the anomalous northeasterly winds over the north Indian Ocean are anchored by IPOC mechanism during the postEl Niño summer. Mishra et al. (2012) also found that the dipole pattern of rainfall anomalies during the monsoon over India are related to a general warming of the tropical Indian Ocean during the post-El Niño summer (see also Chowdary et al. 2017, 2018). General circulation model (GCM) studies of Zhou et al. (2018) also show that El Niño-related surface temperature anomalies are larger in post-El Niño summers than in El Niño developing summers over South Asia. Over Southeast Asia, SAT anomalies are much larger during spring than the following summer (Figs. 10b,c), due possibly to the earlier monsoon onset than over South Asia. Thirumalai et al. (2017) found that record-breaking April extremes of SAT over Southeast Asia tend to occur following El Niño.

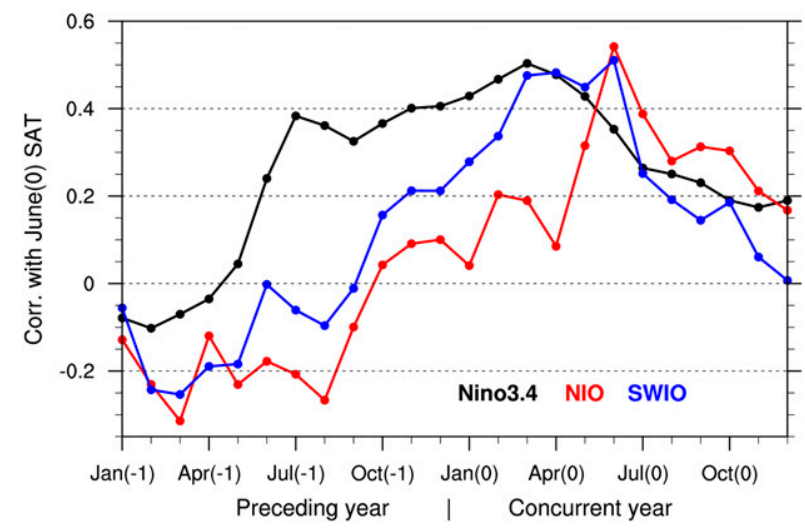

FIG. 11. Lagged correlations with June(0) SAT index over central India $\left(18^{\circ}-28^{\circ} \mathrm{N}, 76^{\circ}-86^{\circ} \mathrm{E}\right.$; blue box in Fig. 2$)$ on the interannual time scale based on JRA-55 dataset for 1958-2013: Niño-3.4 index (black); SST over the northern Indian Ocean (NIO; $0^{\circ}-20^{\circ} \mathrm{N}, 40^{\circ}-100^{\circ} \mathrm{E}$; red) and the southwestern Indian Ocean (SWIO; $15^{\circ}-5^{\circ} \mathrm{S}, 50^{\circ}-80^{\circ} \mathrm{E}$; blue). Years -1 and 0 denote the preceding and concurrent years of the June SAT index, respectively. A 9-yr running mean is preapplied (separately for each calendar month) to remove decadal and longer variations. For the 56-yr time series, a correlation of 0.41 reaches the $99 \%$ significance level based on the $t$ test.

Figure 11 compares the lagged correlation of June SAT over central India $\left(18^{\circ}-28^{\circ} \mathrm{N}, 76^{\circ}-86^{\circ} \mathrm{E}\right.$; blue box in Fig. 2) with Niño-3.4 (black), SSTs in the northern Indian Ocean (NIO; $0^{\circ}-20^{\circ} \mathrm{N}, 40^{\circ}-100^{\circ} \mathrm{E}$; red) and the southwestern Indian Ocean (SWIO; $15^{\circ}-5^{\circ} \mathrm{S}, 50^{\circ}-$ $80^{\circ} \mathrm{E}$; blue) during $1958-2013$. A correlation of 0.41 reaches the $99 \%$ significance level based on a $t$ test. The correlation with El Niño-3.4 peaks in preceding March at 0.5, indicating an ENSO influence during the decay phase. Additional evidence for the IPOC includes high concurrent correlations with SWIO and NIO SST.

There is also a marginal correlation between June SAT and concurrent Niño-3.4 (Fig. 11), suggesting an ENSO influence during the developing phase. Figure 12 shows lagged correlations of India SAT with the winter of $\operatorname{Nov}(0)-\operatorname{Jan}(1)[\mathrm{ND}(0) \mathrm{J}(1)]$ Niño-3.4 based on the CRU TS4.01 dataset for 1901-2016 during the decay phase of ENSO. The correlation is highly significant over India in post-El Niño June $(r>0.4)$. (A correlation of 0.29 reaches the $99 \%$ significance level based on $t$ test for 116-yr time series). This confirms that a warm India in June is associated with the El Niño-induced northern Indian Ocean warming. The correlation between India SAT and antecedent ENSO decays rapidly in July(1) and August(1).

\section{Summary and discussion}

We have investigated year-to-year variability of June SAT over central India and the underlying physical 

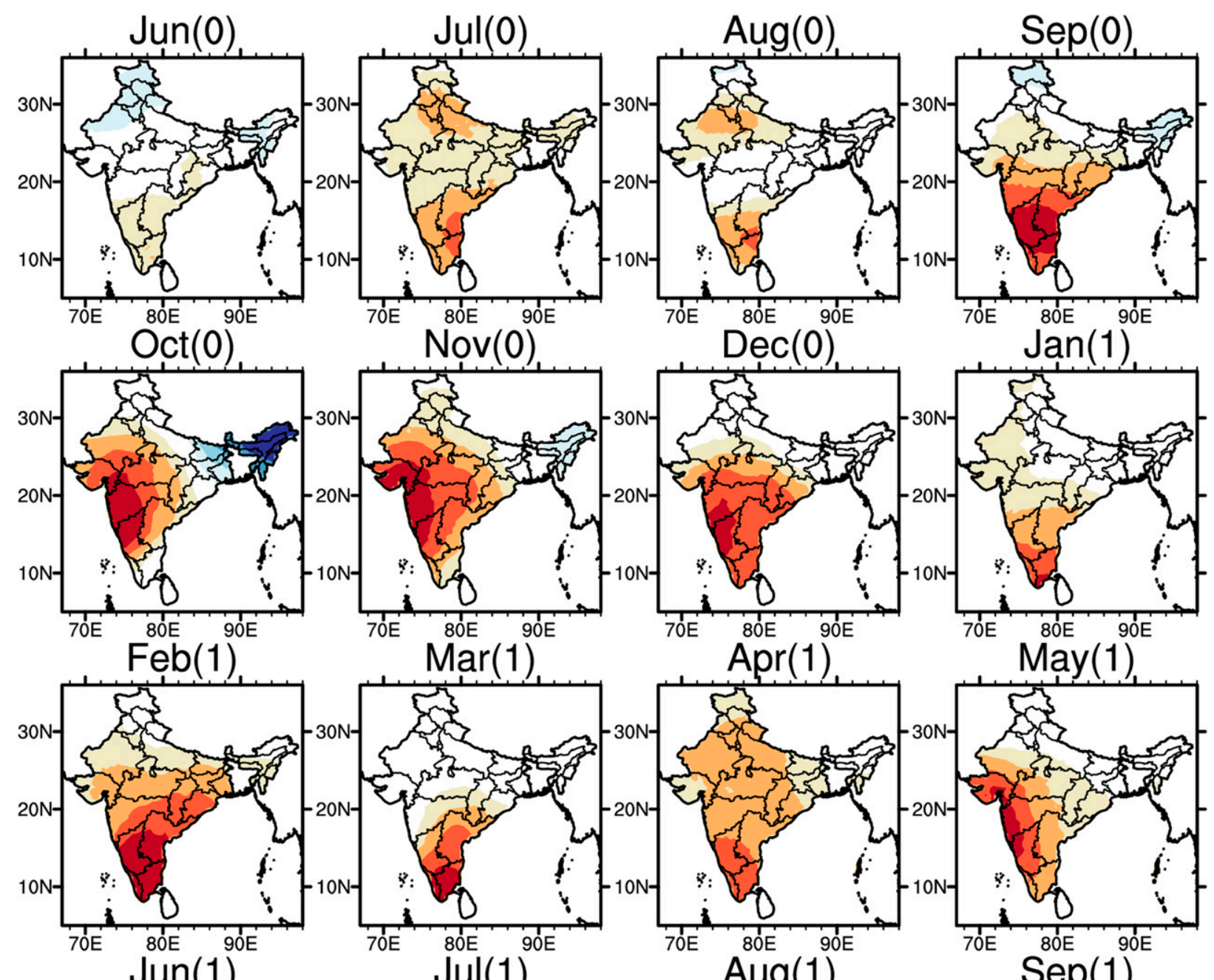

$-30 N-$
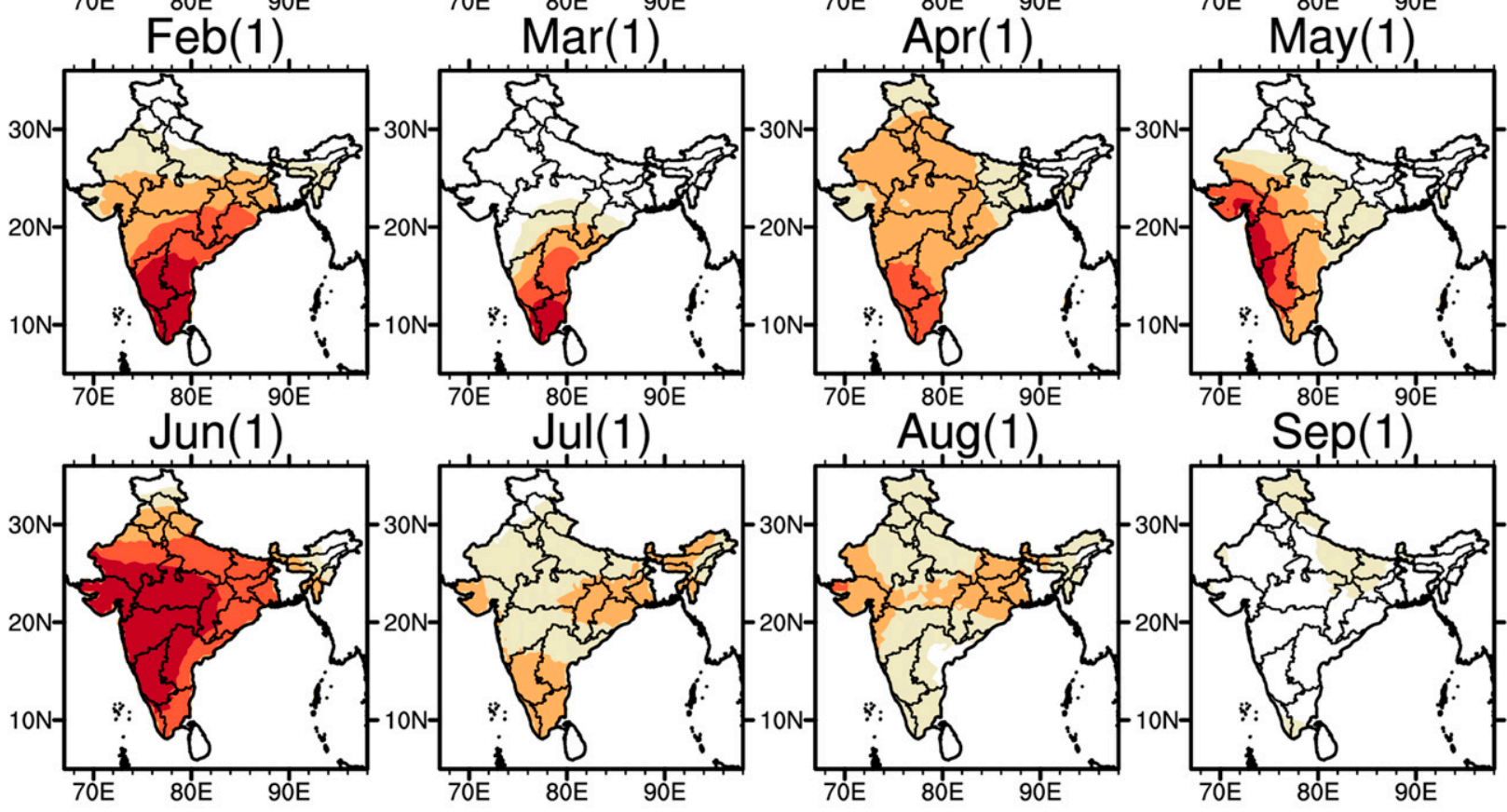

Aug(1)
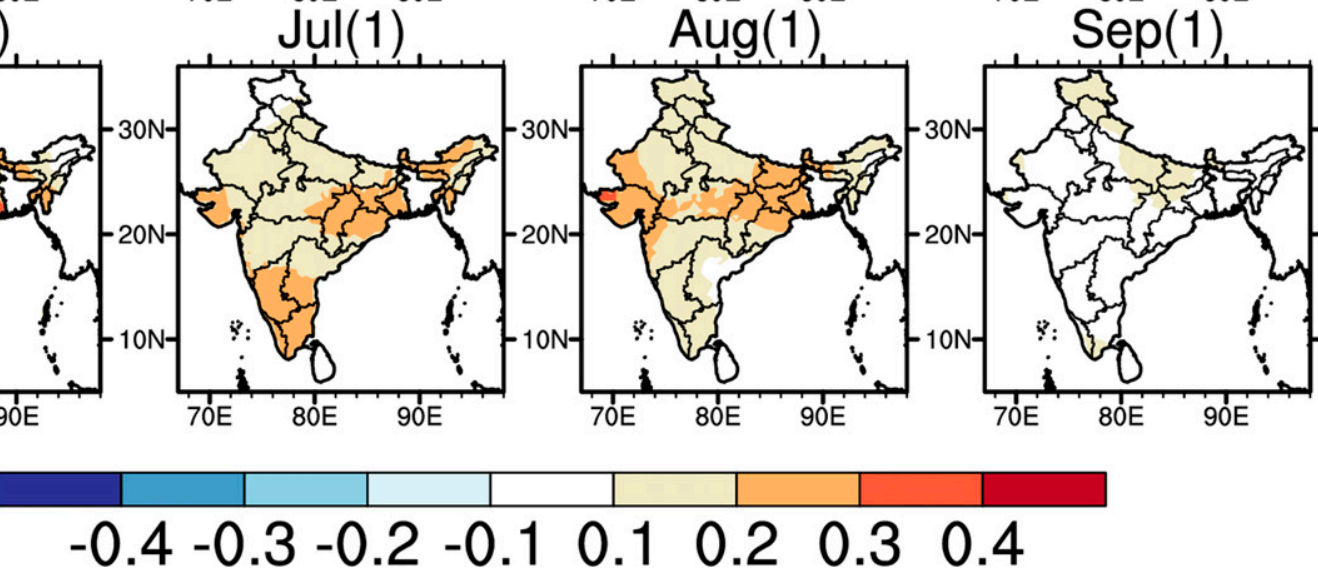

FIG. 12. Lagged correlations of SAT over India with the ND(0)J(1) Niño-3.4 index based on CRU TS4.01 dataset for 1901-2016. Years 0 and 1 denote the developing and decay years of an El Niño event, respectively. For 116-yr time series, a correlation of 0.29 (0.22) reaches the $99 \%(95 \%)$ significance level based on the $t$ test.

mechanisms based on various observations. Central India SAT shows a prominent year-to-year variability in June with a standard deviation above $1.25^{\circ} \mathrm{C}$. The transition over central India from the hot premonsoon to the cooler monsoon takes place around 9 June, which is the climatological onset date of local summer monsoon. Daily mean SAT decreases markedly with the abrupt onset of monsoonal rainfall in June (Figs. 1 and 5). 
Positive SAT anomalies of June are associated with a delayed ISM onset and tend to occur during post-El Niño summers.

ISM onset variability is strongly modulated by the ISO (Murakami et al. 1986). Before the ISM onset, suppressed ISO convection controls central India and the northeast Arabian Sea on 25 May, which continues to advance northeastward to cover most of the Indian peninsula in the subsequent 2 weeks (left panels in Fig. 7). This premonsoon intraseasonal dry spell often causes severe heat waves over the whole country (e.g., Joseph et al. 1994; Wang et al. 2009). Active ISO convection is initiated in the equatorial western Indian Ocean on 25 May and moves northeastward to reach central India around 9 June, and then the ISM rainy season over central India begins. The wind anomalies turn from northeasterly to southwesterly over central India with the ISM onset. Central India SAT decreases sharply following the ISM onset from 30 May to 18 June (Figs. 1 and 5).

An EOF analysis is performed on interannual variability in daily SAT over central India from 28 May to 19 June during 1958-2013 (Fig. 4). Monthly mean SAT variability over central India in June is dominated by the first mode with correlation coefficient at 0.92 . In its positive phase, EOF1 represents a late ISM onset with the active ISO convection reaching central India on 18 June (right panels in Fig. 7), causing positive SAT anomalies over central India in June. Meanwhile, June rainfall anomalies exhibit a dipole structure with depressed rainfall over central and northern India and enhanced rainfall over peninsular India (Fig. 8b). This dipole pattern of rainfall anomalies in June resembles the second mode of interannual variability in JuneSeptember mean ISMR (Mishra et al. 2012). They found that this dipole mode of ISMR variability in India is related to the tropical Indian Ocean warming during post-El Niño summers.

Further analysis suggests that positive SAT anomalies of June over central India are associated with positive SST anomalies over the equatorial eastern-central Pacific and Indian oceans induced by El Niño in developing and decay years, respectively. Indeed, El Niño induces northeasterly wind anomalies and positive SST anomalies over the northern Indian Ocean through the IPOC mechanism during spring and summer, causing anomalous warming over India in June by delaying the ISM onset. Likewise, during the El Niño-developing summer, SST anomalies in the central and eastern Pacific induce anomalous descent over India by slowing down the Walker circulation.

Extreme events such as floods, droughts, heat waves, and cold surges have increased globally including India under anthropogenic warming (De et al. 2005; Mazdiyasni et al. 2017; Thirumalai et al. 2017) and the predictive understanding of regional climate anomalies (including modes of variability) remains a great challenge for the climate research community to meet urgent social needs of mitigating climate change (Xie et al. 2015; Collins et al. 2018). Our results show that heat waves over India are related to a wide range of variability including ISO, ISM, and ENSO.

Acknowledgments. We wish to thank Jinbao Li for useful discussions. This work was supported by the China National 973 Project (2015CB453203), the National Natural Science Foundation of China (41805044, 41661144017), National Postdoctoral Program for Innovative Talents (BX20180066), China Postdoctoral Science Foundation (2018M632008), and the U.S. National Science Foundation (1637450). The Japanese 55year Reanalysis is provided by the Research Data Archive at the National Center for Atmospheric Research, Computational and Information Systems Laboratory. Plots are created with the NCAR Command Language (http://dx.doi.org/10.5065/D6WD3XH5). Data are processed with the Climate Data Operators.

\section{REFERENCES}

Ananthakrishnan, R., and M. K. Soman, 1988: The onset of the southwest monsoon over Kerala: 1901-1980. J. Climatol., 8, 283-296, https://doi.org/10.1002/joc.3370080305.

— U. U. Acharya, and A. R. Ramakrishnan, 1967: On the criteria for declaring the onset of southwest monsoon over Kerala. India Meteorological Department Forecasting Manual IV, 18-1, IMD, $52 \mathrm{pp}$.

Biasutti, M., and Coauthors, 2018: Global energetics and local physics as drivers of past, present and future monsoons. Nat. Geosci., 11, 392-400, https://doi.org/10.1038/s41561-018-0137-1.

Bryson, R. A., and W. H. Campbell, 1982: Year-in-advance forecasting of the Indian monsoon rainfall. Environ. Conserv., 9, 51-56, https://doi.org/10.1017/S0376892900019536.

Chowdary, J., N. John, and C. Gnanaseelan, 2014: Interannual variability of surface air-temperature over India: Impact of ENSO and Indian Ocean Sea surface temperature. Int. J. Climatol., 34, 416-429, https://doi.org/10.1002/joc.3695.

- , H. S. Harsha, C. Gnanaseelan, G. Srinivas, A. Parekh, P. Pillai, and C. V. Naidu, 2017: Indian summer monsoon rainfall variability in response to differences in the decay phase of El Niño. Climate Dyn., 48, 2707-2727, https://doi.org/ 10.1007/s00382-016-3233-1.

—, G. Srinivas, Y. Du, K. Gopinath, C. Gnanaseelan, A. Parekh, and P. Singh, 2018: Month-to-month variability of Indian summer monsoon rainfall in 2016: Role of the Indo-Pacific climatic conditions. Climate Dyn., https://doi.org/10.1007/ s00382-018-4185-4.

Collins, M., and Coauthors, 2018: Challenges and opportunities for improved understanding of regional climate dynamics. Nat. Climate Change, 8, 101-108, https://doi.org/10.1038/ s41558-017-0059-8. 
De, U. S., R. K. Dube, and G. P. Rao, 2005: Extreme weather events over India in the last 100 years. J. Ind. Geophys. Union, 9, 173-187.

Fasullo, J., and P. Webster, 2003: A hydrological definition of Indian monsoon onset and withdrawal. J. Climate, 16, 3200-3211, https://doi.org/10.1175/1520-0442(2003)016<3200a: AHDOIM $>2.0 . \mathrm{CO} ; 2$

Gadgil, S., 2003: The Indian monsoon and its variability. Annu. Rev. Earth Planet. Sci., 31, 429-467, https://doi.org/10.1146/ annurev.earth.31.100901.141251.

— , and S. Gadgil, 2006: The Indian monsoon, GDP and agriculture. Econ. Polit. Wkly., 41, 4887-4895.

Goswami, B., G. Wu, and T. Yasunari, 2006: The annual cycle, intraseasonal oscillations, and roadblock to seasonal predictability of the Asian summer monsoon. J. Climate, 19, 50785099, https://doi.org/10.1175/JCLI3901.1.

Harris, I., P. D. Jones, T. J. Osborn, and D. H. Lister, 2014: Updated high-resolution grids of monthly climatic observationsThe CRU TS3.10 dataset. Int. J. Climatol., 34, 623-642, https:// doi.org/10.1002/joc.3711.

Huang, B., and Coauthors, 2017: Extended reconstructed sea surface temperature, version 5 (ERSSTv5): Upgrades, validations, and intercomparisons. J. Climate, 30, 8179-8205, https:// doi.org/10.1175/JCLI-D-16-0836.1.

Ito, H., N. C. Johnson, and S.-P. Xie, 2013: Subseasonal and interannual temperature variability in relation to extreme temperature occurrence over East Asia. J. Climate, 26, 9026-9042, https://doi.org/10.1175/JCLI-D-12-00676.1.

Joseph, P., J. K. Eischeid, and R. J. Pyle, 1994: Interannual variability of the onset of the Indian summer monsoon and its association with atmospheric features, El Niño, and sea surface temperature anomalies. J. Climate, 7, 81-105, https:// doi.org/10.1175/1520-0442(1994)007<0081:IVOTOO >2.0.CO;2.

_ process over South Asia and an objective method for the date of monsoon onset over Kerala. Int. J. Climatol., 26, 1871-1893, https://doi.org/10.1002/joc.1340.

Knowlton, K., and Coauthors, 2014: Development and implementation of South Asia's first heat-health action plan in Ahmedabad (Gujarat, India). Int. J. Environ. Res. Public Health, 11, 3473-3492, https://doi.org/10.3390/ ijerph110403473.

Kobayashi, S., and Coauthors, 2015: The JRA-55 reanalysis: General specifications and basic characteristics. J. Meteor. Soc. Japan, 93, 5-48, https://doi.org/10.2151/jmsj.2015-001.

Kosaka, Y., S.-P. Xie, N.-C. Lau, and G. A. Vecchi, 2013: Origin of seasonal predictability for summer climate over the Northwestern Pacific. Proc. Natl. Acad. Sci. USA, 110, 7574-7579, https://doi.org/10.1073/pnas.1215582110.

Kumar, K. K., B. Rajagopalan, and M. A. Cane, 1999: On the weakening relationship between the Indian monsoon and ENSO. Science, 284, 2156-2159, https://doi.org/10.1126/ science.284.5423.2156.

Lee, H.-T., 2014: Climate algorithm theoretical basis document (C-ATBD): Outgoing longwave radiation (OLR) -Daily. NOAA's Climate Data Record (CDR) Program, CDRATBD-0526, 46 pp., http://www1.ncdc.noaa.gov/pub/data/sds/ cdr/CDRs/Outgoing\%20Longwave\%20Radiation\%20-\%20Daily/ AlgorithmDescription.pdf.

Li, C., and M. Yanai, 1996: The onset and interannual variability of the Asian summer monsoon in relation to land-sea thermal contrast. J. Climate, 9, 358-375, https://doi.org/10.1175/ 1520-0442(1996)009<0358:TOAIVO>2.0.CO;2.
Lu, E., X. Zeng, Z. Jiang, Y. Wang, and Q. Zhang, 2009: Precipitation and precipitable water: Their temporal-spatial behaviors and use in determining monsoon onset/retreat and monsoon regions. J. Geophys. Res., 114, D23105, https://doi.org/ 10.1029/2009JD012146.

Mazdiyasni, O., and Coauthors, 2017: Increasing probability of mortality during Indian heat waves. Sci. $A d v ., 3$, e1700066, https://doi.org/10.1126/sciadv.1700066.

Mishra, V., B. V. Smoliak, D. P. Lettenmaier, and J. M. Wallace, 2012: A prominent pattern of year-to-year variability in Indian summer monsoon rainfall. Proc. Natl. Acad. Sci. USA, 109, 7213-7217, https://doi.org/10.1073/pnas.1119150109.

Misra, V., A. Bhardwaj, and A. Mishra, 2018: Local onset and demise of the Indian summer monsoon. Climate Dyn., 51, 1609-1622, https://doi.org/10.1007/s00382-017-3924-2.

Murakami, T., L.-X. Chen, and A. Xie, 1986: Relationship among seasonal cycles, low-frequency oscillations, and transient disturbances as revealed from outgoing longwave radiation data. Mon. Wea. Rev., 114, 1456-1465, https://doi.org/10.1175/ 1520-0493(1986)114<1456:RASCLF>2.0.CO;2.

Nitta, T., 1987: Convective activities in the tropical western Pacific and their impact on the Northern Hemisphere summer circulation. J. Meteor. Soc. Japan, 65, 373-390, https://doi.org/ 10.2151/jmsj1965.65.3_373.

Noska, R., and V. Misra, 2016: Characterizing the onset and demise of the Indian summer monsoon. Geophys. Res. Lett., 43, 45474554, https://doi.org/10.1002/2016GL068409.

Pai, D., and M. Rajeevan, 2007: Indian summer monsoon onset: Variability and prediction. National Climate Centre Research Rep. 4/2007, 27 pp.

Parthasarathy, B., K. Rupa Kumar, and A. Munot, 1992: Forecast of rainy season foodgrain production based on monsoon rainfall. Indian J. Agric. Sci., 62, 1-8.

- - A. Munot, and D. Kothawale, 1994: All-India monthly and seasonal rainfall series: 1871-1993. Theor. Appl. Climatol. Climatol., 49, 217-224, https://doi.org/10.1007/BF00867461.

Qi, Y., R. Zhang, T. Li, and M. Wen, 2008: Interactions between the summer mean monsoon and the intraseasonal oscillation in the Indian monsoon region. Geophys. Res. Lett., 35, L17704, https://doi.org/10.1029/2008GL034517.

Rao, Y., 1976: Southwest Monsoon. Meteorological MonographSynoptic Meteorology No. 1/1976, India Meteorological Department, $367 \mathrm{pp}$.

Rasmusson, E. M., and T. H. Carpenter, 1983: The relationship between eastern equatorial Pacific sea surface temperatures and rainfall over India and Sri Lanka. Mon. Wea. Rev., 111, 517-528, https:// doi.org/10.1175/1520-0493(1983)111<0517:TRBEEP > 2.0.CO;2.

Sperber, K. R., and H. Annamalai, 2014: The use of fractional accumulated precipitation for the evaluation of the annual cycle of monsoons. Climate Dyn., 43, 3219-3244, https:// doi.org/10.1007/s00382-014-2099-3.

Srinivas, G., J. S. Chowdary, Y. Kosaka, C. Gnanaseelan, A. Parekh, and K. V. Prasad, 2018: Influence of the PacificJapan pattern on Indian summer monsoon rainfall. J. Climate, 31, 3943-3958, https://doi.org/10.1175/JCLI-D-17-0408.1.

Taniguchi, K., and T. Koike, 2006: Comparison of definitions of Indian summer monsoon onset: Better representation of rapid transitions of atmospheric conditions. Geophys. Res. Lett., 33, L02709, https://doi.org/10.1029/2005GL024526.

Thirumalai, K., P. N. DiNezio, Y. Okumura, and C. Deser, 2017: Extreme temperatures in Southeast Asia caused by El Niño and worsened by global warming. Nat. Commun., 8, 15531, https://doi.org/10.1038/ncomms15531. 
Wahl, E. R., and C. Morrill, 2010: Toward understanding and predicting monsoon patterns. Science, 328, 437-438, https:// doi.org/10.1126/science.1188926.

Wang, B., Q. Ding, and P. Joseph, 2009: Objective definition of the Indian summer monsoon onset. J. Climate, 22, 3303-3316, https://doi.org/10.1175/2008JCLI2675.1.

Wu, R., and S. W. Yeh, 2010: A further study of the tropical Indian Ocean asymmetric mode in boreal spring. J. Geophys. Res., 115, D08101, https://doi.org/10.1029/2009JD012999.

Xavier, P. K., C. Marzin, and B. Goswami, 2007: An objective definition of the Indian summer monsoon season and a new perspective on the ENSO-monsoon relationship. Quart. J. Roy. Meteor. Soc., 133, 749-764, https://doi.org/10.1002/ qj. 45.

Xie, S.-P., and Z.-Q. Zhou, 2017: Seasonal modulations of El Niñorelated atmospheric variability: Indo-western Pacific Ocean feedback. J. Climate, 30, 3461-3472, https://doi.org/10.1175/ JCLI-D-16-0713.1.

K. Hu, J. Hafner, H. Tokinaga, Y. Du, G. Huang, and T. Sampe, 2009: Indian Ocean capacitor effect on Indowestern Pacific climate during the summer following El Niño. J. Climate, 22, 730-747, https://doi.org/10.1175/ 2008JCLI2544.1.
_ and Coauthors, 2015: Towards predictive understanding of regional climate change. Nat. Climate Change, 5, 921-930, https://doi.org/10.1038/nclimate2689.

—, Y. Kosaka, Y. Du, K. Hu, J. S. Chowdary, and G. Huang, 2016: Indo-western Pacific Ocean capacitor and coherent climate anomalies in post-ENSO summer: A review. Adv. Atmos. Sci., 33, 411-432, https://doi.org/10.1007/s00376-015-5192-6.

Zeng, X., and E. Lu, 2004: Globally unified monsoon onset and retreat indexes. J. Climate, 17, 2241-2248, https://doi.org/ 10.1175/15200442(2004)017<2241:GUMOAR>2.0.CO;2.

Zhang, J., L. Wu, and W. Dong, 2011: Land-atmosphere coupling and summer climate variability over East Asia. J. Geophys. Res., 116, D05117, https://doi.org/10.1029/2010JD014714.

Zhang, R., 2001: Relations of water vapor transport from Indian monsoon with that over East Asia and the summer rainfall in China. Adv. Atmos. Sci., 18, 1005-1017.

—, A. Sumi, and M. Kimoto, 1996: Impact of El Niño on the East Asian monsoon. J. Meteor. Soc. Japan, 74, 49-62, https:// doi.org/10.2151/jmsj1965.74.1_49.

Zhou, Z.-Q., S.-P. Xie, G. J. Zhang, and W. Zhou, 2018: Evaluating AMIP skill in simulating interannual variability over the Indowestern Pacific. J. Climate, 31, 2253-2265, https://doi.org/10.1175/ JCLI-D-17-0123.1. 